\title{
On the Intermediary Effect of Organizational Policy: The Effect of Perceived Ethical Climate on Corruption Behavior of Teachers
}

\author{
Fatmanur Özen \\ Correspondence: Fatmanur Özen, Faculty of Education, Giresun University, Giresun, Turkey. \\ Received: April 24, 2018 \\ doi:10.11114/jets.v6i8.3238 \\ Accepted: May 28, $2018 \quad$ Online Published: June 8, 2018 \\ URL: https://doi.org/10.11114/jets.v6i8.3238
}

\begin{abstract}
Employees want to benefit from more sources of the organization to achieve their own goals in the direction of individual desires, which made them rivals in the sharing of income, responsibility, and promotion regarding the organization; thus, in organizations, political processes began to appear. Perceptions of what is considered ethically correct and how ethical issues are addressed within an organization constitutes the ethical climate of the organization. According to social psychology, behaviors of the individual are the function of the psychological environment perceived by the individual in which he or she is living or working. In that case, positively or negatively perceived organizational ethical climate has the possibility of reducing or increasing unethical behavior under the influence of organizational policy perception. In other words, corruption behavior, which means an employee's using public resources or power for his/her own interests, is likely to be affected both by organizational ethical climate and organizational policy perceptions. To examine these effects relational type path analysis used. The data were collected with "Organizational: Policy Perception, Ethical Climate, and Corruption" scales. Although the results of the research did not confirm the model established to determine the effect of ethical climate on teachers' corruption behavior under the intermediary influence of organizational policy; the ethical climate perceived as socially responsible and ruled are determined to have the effect of reducing the corruption behavior, while the attitude of superordinate and workmates of organizational policy perception have an increasing effect on the corruption behavior of teachers.
\end{abstract}

Keywords: organizational ethical climate, organizational policy, corruption, educational organizations

\section{Introduction}

Bursalığlu (2002) states that "politics and administration cannot be precisely separated from each other; moreover, this cannot be advised" (p. 220). Mintzberg (1983) describes organizations as political arenas. In order to be effective in these arenas, it is not sufficient only to have the political will to enter these arenas, but besides, it is necessary to manage this will effectively. Organizational policy (politics) affects all processes belonging to the organization (Chang, Rosen \& Levy, 2009). According to Kacmar and Baron (1999), this impact may be related to the effectiveness of the organization such as organizational decisions and the distribution of organizational resources; besides, it may include situations related to efficiency such as assessment of organizational performance. Although the schools (pre, primary and secondary schools at the elementary education level and high schools at the secondary education level) at the compulsory education level affiliated with the Ministry of National Education (MoNE) in the Turkish education system are often financed by the budget provided by the gross national product and allocated to the schools by MoNE; and although all school administrators are appointed among experienced teachers according to the results of the "evaluation form" and the "oral exam" (Regulation on the Assignment of Administrators to Educational Institutions of MoNE, 2017) applied by the provincial organizations of MoNE -outside the will of other administrators and teachers working in school, parents and students - and although the teachers who work in the schools affiliated with MoNE are appointed by a central system, it is predicted that all of these have not removed the possibility of corruption behavior in the educational organizations affiliated with the Republic of Turkey.

Drucker (2009/2012) expresses the need to redefine the scope of management and with new assumptions, he argues that "the scope of management science, as both a science and a practice, should be liberated from legal regulations and should be a functional process focused on performance and outcomes" (p. 139). Thus, employees of the organization will be able to join in the groups they work within the organization or legitimate activities that benefit the organization or some political activities that have been subjected to sanctions by the organization. Treadway et al. (2004) argue that managers who are good politicians can develop strong bonds based on social capital to increase the resources they 
provide for their subordinates. On the other hand, employees may take part in illegitimate political activities such as forming a coalition, payment, and promotion based on favoritism and backing up based on completely protecting one's own interests and generally not to the welfare or well-being of the organization or colleagues (Ferris, Russ \& Fandt, 1989). Thus, although Hippocrates's "primum non-nocere" (first, to do no harm) principle is adopted as one of the basic ethical rules for organizations that offer all services and goods, not just medicine, during services or in the relations among employees; it is assumed that there may be organizational activities in addition to this.

\subsection{Organizational Policy}

Organizational policy can be defined as organization-oriented and employee-oriented. According to organization-oriented definitions, the organizational policy is "...variety of activities associated with the use of influence tactics to improve ... organizational interests" (Jarrett, 2017) while, for employees, it is "the behaviors that one has adopted to serve oneself at the expense of others, other people, and possibly organization" (McShane \& Von Glinov, 2014/2016, p. 190). It is known that organizational policy perception increases in organizations whose resources are scarce and distribution procedures are not transparent, where the decisions are taken do not guide the use of resources, organizational change is not effectively managed, the self-serving and self-empowering behavior of the leaders of the organization increase, there are role ambiguities and poor performance appraisal systems, employees do not trust each other, and employees with Machiavellian values are employed. The reactions of the organization and the management of the organization to all these negativities reduce or increase the frequency of showing political behavior in organizations (McShane \& Von Glinov, 2014/2016, pp. 190-191; Robbins \& Judge, 2011/2012, p. 433; Rong \& Cao, 2015).

\subsection{Ethics, Ethical Climate}

Ethics is the code of moral principles that guide the behaviors of a person, group, or organization, and "that constitute the boundaries of truth or wrong, good or evil." Among various alternatives of action, it aims to create behavioral principles that will "help people in choosing the right" (Holt, 1987, p. 697). Thus, the paths of the purpose of ethics and moral rules intersect. While attempting to embody ethics as "philosophy of ethics" (Çalışlar, 1983, p.135), Ricoeur (1981) makes a distinction between ethical purpose and ethical rule: The ethical purpose is based on Aristotelian thought and it is "to aim good life". The moral rule is "based on Kant's conservatism and it is an obligation to obey the rule." For this reason, a person must first have ethics in order to have morals; the ethical purpose must go through the sieve of the rule. However, if the rule comes to a dead end in practice, it may be legitimate to resort to the purpose in this case (Ref. by Heynes, 1998/2014, p. 21). Thus, ethics and ethical behavior both in terms of individual and organization may require a dynamic thought and practice to be reconsidered when the ethical rules come to a dead end.

Three basic principles of ethics are utilitarianism (consequentialist or teleological theory), individual rights and distributive justice. Utilitarianism is the effort to provide the best for the greatest number of people (Aydın, 2013). Utilitarianism can create contradictions because it is almost impossible to evaluate the benefits or costs of many decisions to be taken especially when it comes to the diverse needs and values of a large number of stakeholder groups. Individual rights are an ethical principle that indicates that all employees have rights that allow them to engage in behaviors in a clearly framed boundary. However, some individual rights within the organization may conflict with others and this can create problems. Distributive justice is related to the necessity that individuals with similar status in the organization should have similar benefits and obligations. According to the distributive justice, two employees contributing equally to their work should receive similar awards. Inequality may be legitimized among the awards only if it will benefit people in the lower welfare level in the society. However, the basic problem of distributive justice arises when determining who are "similar" and which factors are "appropriate" for this situation (McShane \& Von Glinov, 2014/2016, pp. 37-38).

The climate that expresses the quality of organizational life is related to the way employees perceive the current conditions in the organization. Climate, which reveals the nature of human relations in an organization, is a psychological definition of the organization in a sense (Dönertaş, 2008). Ethical climate, according to Victor \& Cullen (1988), includes moral attitudes and behaviors generated by organizational values, practices, and programs. With its rules, standards, codes, and principles of ethics, organizational ethical climate guides morally correct behaviors in the organization (Lewis, 1985). Thus, the climate including the ethics in the organization is the desired and expected state of organizational climate (Özen \& Durkan, 2016). Ethical climate defines the value system of the organization, reveals organizational goals, ensures that various alternatives are taken into account in the evaluation of the problems and decisions are taken in accordance with the principles adopted by the organization (Neale \& Northarafts, 1991). It informs employees about acceptable and unacceptable behavior within the organization (Barnett \& Schubert, 2002). However, considering the basic principles of ethics, ethics, moral rules, the dilemmas of ethics and ethical behavior, it is understood that organizational ethical climate may be a guide for the employees of the organization, and in some cases, it may lead to contradictions. Victor and Cullen (1988) identified nine different organizational ethical climate types for non-profit organizations. Experimental research has shown that five of these ethical climates actually exist: Caring, 
rules, instrumental, efficiency and independence (Deshpande, 1996; Victor \& Cullen, 1987). Caring ethical climate is the most common ethical climate and employees work for the good of those inside or outside of the organization. Philanthropy both at the individual and organization level is at the forefront (Deshpande, 1996). In rules ethical climate type, the principles followed belong to the institution (institutional policies, programs, rules, and norms) (Akbaş, 2010). The independence climate depends on one's ethical beliefs and is only at the individual level of analysis. The climate of laws and principles is only found at the level of universal analysis, and in this climate, the employees follow laws and codes of professional ethics. Instrumental ethical climate has egoistic features and is based on maximizing personal benefit both at the individual and organizational level (Wang \& Hsieh, 2013, Ref. by Tütüncü \& Savran, 2007). The results of the research conducted by Özen and Durkan (2016) on educational organizations indicated that there are instrumental, efficiency, caring, socially responsible, legal and principled, independence and regular organizational ethical climate types in educational organizations; thus, eight of nine types of ethical climate theoretically defined in educational organizations are perceived by the teachers.

Research carried to this day have shown that perceived ethical climate has negatives effects on the employees of the organization such as reducing job satisfaction, providing acquiescent silence, reducing loyalty to the organization and increasing unethical behavior (Appelbaum, Deguire \& Lay, 2005; Deshpande, 1996; Duh, Belak \& Milfelner, 2010; Elci \& Alpkan, 2009; Wimbush \& Shepard, 1994) while it also has some positive effects such as promoting co-operation, strengthening organizational loyalty and increasing organizational citizenship behavior (Elçi, 2005; Eser, 2007; Moore \& Moore, 2014; Sağnak, 2005).

\subsection{Unethical Behaviors: Corruption}

Unethical behavior is individuals, groups or organizations' abandoning the ethical rules and principles accepted as good, nice and right by the society and profession and showing behaviors violating these rules and principle (Sökmen, 2003; Sökmen, Ekmekçioğlu \& Çelik, 2015). Brass, Butterfield and Skaggs (1998) suggest that there are factors related to the individual (level of will, cognitive and moral development, level of having Machiavellian values); organizational (climate, performance evaluation system and form, norms, codes of organizational behavior) and job/task (magnitude of consequences, social consensus, probability of effect, proximity) reasons that cause unethical behavior. Also, the structure of relationships among organizational employees in the organization (power, status, asymmetry, clicks, centrality) affects the frequency of emergence of individual, managerial and organizational unethical behaviors.

Corruption from unethical behaviors is the illegal use of authority by an employee for profit (Akçakaya \& Hasanoğlu, 2009). When corruption is regarded as a problem of the organization, it means the employee's not doing what he/she has to do or doing what he/she must not do (Özdemir, 2008). Employees' violating rules and regulations or speeding up or slowing down jobs to achieve tangible or intangible purposes is called corruption actions (Gül, 2006). Field surveys show that corruption in organizations is influenced by culture, national culture, attitudes towards work, egoist ethical climate, future orientation discrepancy, weak personal and social norms (Balc1 et al., 2012; Gelbrich, Stedham \& Gäthke, 2016; Gorsira et al. 2018; Jahić \& Činjarević, 2017).

In this research, the influence of perceived organizational ethical climate on the corruption behavior of teacher is examined under the influence of the intermediary role of organizational policy perception.

\section{Method}

The research examined teachers' organizational policy perception, ethical climate perception and unethical (corruption) behaviors and the relationships between these perceptions and behaviors. In this regard, the research is a correlational research. Correlational studies are the studies in which the relationship between two or more variables is examined without interfering with these variables in any way (Büyüköztürk et al., 2014). The main goal of the correlational research is to understand important phenomena defined by the relationship between variables (Fraenkel, Wallen \& Hyun, 2012).

\subsection{Data Collection Tools}

Three data collection tools were used in this study. This measurement tools can be identified as follows:

\subsubsection{Organizational Policy Perception Scale}

The scale developed by Kacmar and Ferris (1991) contains 31 items. The scale has the five-point Likert-type rating structure. The scale was developed for the employees in profit-making companies and it includes five sub-dimensions: "Doing what is necessary for promotion, Self-seeking, Behaviors of the Superordinate and Workmates, Clicks and Promotion-Salary Practices". Items 2, 4, 16, 18, 26 in the scale are scored reversely. The scale was adapted to Turkish by Erol (2014) to collect data from the lecturers. However, since the scale will be applied to the teachers working in the field in this research, the scale items have been rearranged in accordance with the institutional structure and management of educational organizations. The adaptation was carried out by four educational management audit specialists (two assistant professors, two teachers who have done master's non-thesis in this field) and two specialist sociologists (one professor, one doctoral student). To test whether the prepared scale maintained the factorial structure 
of its original form, the scale was applied to 358 teachers from various branches working in primary education and secondary education institutions in the city of Giresun/Turkey. The obtained data was transferred to IBM-SPSS 22 and LISREL 8.8 programs. The compliance index scores obtained by confirmatory factor analysis (CFA) applied on this group have been summarized in Table 1 .

Table 1. Compliance values obtained as a result of confirmatory factor analysis

\begin{tabular}{lllllllllll}
\hline$\chi^{2}$ & sv & $\chi^{2} / \mathrm{sv}$ & RMSEA & AGFI & SRMR & RMR & NNFI & CFI & NFI & IFI \\
\hline 2757,52 & 585 & 4,71 & 0,100 & 0,67 & 0,12 & 0,15 & 0,82 & 0,71 & 0,79 & 0,81 \\
\hline
\end{tabular}

The obtained compliance index values are not acceptable values according to the literature (Bentler, 1990; Browne \& Cudeck, 1993; Çokluk, Şekercioğlu \& Büyüköztürk, 2010; Hu \& Bentler, 1999; Jöreskog \& Sörbom, 1993; Kline, 2005; Sümer, 2000; Şimşek, 2007; Vieira, 2011). After determining that the structure of the scale was not confirmed in the target mass of this study, exploratory factor analysis (EFA) was applied to the scale. As a result of this factor analysis, items $1,10,11,21,24,25,26,28,29,30$ and 31 were excluded from the scale because they showed a low item-total correlation. After these items were excluded, a scale structure with five sub-dimensions was obtained. The values of the new structure obtained after the EFA have been given in Table 2.

Table 2. Exploratory factor analysis and reliability analysis results

\begin{tabular}{|c|c|c|c|c|c|c|c|}
\hline \multirow{2}{*}{ Item No. } & \multirow{2}{*}{ The Factor Involving the Item } & \multirow{2}{*}{ Item-Total Correlation } & \multicolumn{5}{|c|}{ Item Load Values in the Factors as a Result of Returning } \\
\hline & & & Factor I & Factor II & Factor III & Factor IV & Factor V \\
\hline i2 & Factor 1 & 0,338 & 0,767 & & & & \\
\hline $\mathrm{m} 3$ & Factor 1 & 0.436 & 0.766 & & & & \\
\hline i4 & Factor 1 & 0,409 & 0.620 & & & & \\
\hline i6 & Factor 1 & 0.403 & 0.587 & & & & \\
\hline i16 & Factor 2 & 0.449 & & 0.726 & & & \\
\hline i 27 & Factor 2 & 0.543 & & 0.664 & & & \\
\hline i19 & Factor 2 & 0.424 & & 0.610 & & & \\
\hline i17 & Factor 2 & 0.655 & & 0.610 & & & \\
\hline i15 & Factor 2 & 0.548 & & 0.520 & & & \\
\hline $\mathrm{i} 22$ & Factor 3 & 0.626 & & & 0.754 & & \\
\hline $\mathrm{i} 23$ & Factor 3 & 0.624 & & & 0.726 & & \\
\hline i18 & Factor 3 & 0.617 & & & 0.636 & & \\
\hline $\mathrm{i} 20$ & Factor 3 & 0.399 & & & 0.529 & & \\
\hline i7 & Factor 4 & 0.317 & & & & 0.810 & \\
\hline i8 & Factor 4 & 0.563 & & & & 0.665 & \\
\hline i9 & Factor 4 & 0.581 & & & & 0.603 & \\
\hline i5 & Factor 4 & 0.616 & & & & 0.567 & \\
\hline i14 & Factor 5 & 0.456 & & & & & 0.739 \\
\hline i13 & Factor 5 & 0.299 & & & & & 0.668 \\
\hline $\mathrm{i} 12$ & Factor 5 & 0.378 & & & & & 0.633 \\
\hline
\end{tabular}

$\mathrm{KMO}=0.899$

Bartlett Sphericity $\left(X^{2}\right)=2886.575 ; \mathrm{sv}=231, \mathrm{p}<0.01$

The Variance Explained by the First Factor $=12.590 \%$; Second Factor $=12.526 \%$; Third Factor $=11.696 \%$

Fourth Factor $=11.273 \%$; Fifth Factor $=9.888 \%$; Five Factors Together $=57.973 \%$

Cronbach Alpha $=0.880$

As a result of the factor analysis conducted, it was determined that the items in the scale showed an item-total correlation of between 0,317 and 0,655. When KMO and Bartlett Sphericity values were examined, it was understood that the data set obtained from 358 teachers was an appropriate data set for factor analysis (Büyüköztürk, 2013; Özdamar, 2013). The five factors that emerged accounted for $58 \%$ of the behavior of interest (organizational policy perception). These values are rather close to the accepted value of $60 \%$ for the scales (Özdamar, 2013). The reliability value of the scale was calculated as 0.880 . Additionally, when the Cronbach Alpha reliability scores of the five subscales were examined individually, it was observed that the obtained values changed between 0.712 and 0.911 . Reliability coefficient values between 0.70 and 0.90 are considered as high reliability for scales (Özdamar, 2013). These subscales have a high level of reliability. The emerging five factors have been renamed as in Table 3. 
Table 3. Organizational policy perception scale sub-dimensions, items and characteristics

\begin{tabular}{|c|c|c|c|c|c|c|}
\hline & & \multicolumn{5}{|c|}{ Sub-dimensions } \\
\hline & & $\begin{array}{c}\text { Doing what is necessary for } \\
\text { promotion (DWNP) - } \\
\text { Organizational Attitude }\end{array}$ & $\begin{array}{l}\text { Doing what is necessary } \\
\text { for promotion (DWNP) - } \\
\text { Individual Attitude }\end{array}$ & Self-seeking Silent & $\begin{array}{l}\text { Self-seeking } \\
\text { Opposition }\end{array}$ & $\begin{array}{c}\text { Attitude of } \\
\text { Superordinate and } \\
\text { Workmates } \\
\end{array}$ \\
\hline \multicolumn{2}{|l|}{ Item } & $2,3,4,6$ & $5,7,8,9 \quad 15,16$ & $, 19,27$ & \multicolumn{2}{|c|}{$18,20,22,23$} \\
\hline Reverse & & 2,4 & None & & None & 18 \\
\hline \multicolumn{2}{|l|}{ 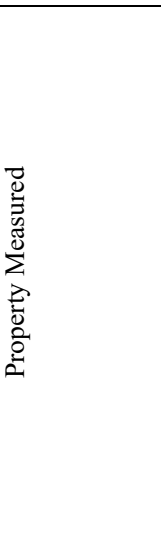 } & $\begin{array}{l}\text { All of the items in this } \\
\text { sub-dimension are included in } \\
\text { the sub-dimension "Doing } \\
\text { What is Necessary for } \\
\text { Promotion" in the original } \\
\text { scale. } \\
\text { Since the statements of } \\
\text { organizational attitude came to } \\
\text { the forefront in the content of } \\
\text { the remaining items of Doing } \\
\text { What is Necessary for } \\
\text { Promotion, this sub-title was } \\
\text { named as "Doing What is } \\
\text { Necessary for } \\
\text { Promotion-Organizational } \\
\text { Attitude". }\end{array}$ & $\begin{array}{l}\text { All of the items in this } \\
\text { sub-dimension are } \\
\text { included in the } \\
\text { sub-dimension "Doing } \\
\text { What is Necessary for } \\
\text { Promotion" in the original } \\
\text { scale. } \\
\text { Since the statements of } \\
\text { individual attitude came to } \\
\text { the forefront in the content } \\
\text { of the remaining items of } \\
\text { Doing What is Necessary } \\
\text { for Promotion, this } \\
\text { sub-title was named as } \\
\text { "Doing What is Necessary } \\
\text { for Promotion-Individual } \\
\text { Attitude". }\end{array}$ & $\begin{array}{l}\text { All of the items under } \\
\text { this factor, except for } \\
\text { the item } 27 \text {, are } \\
\text { included in the } \\
\text { "Self-seeking" } \\
\text { sub-dimension in the } \\
\text { main scale. Item } 27 \text { is } \\
\text { under the "Clicks" } \\
\text { sub-dimension in the } \\
\text { original scale. Since } \\
\text { the rest of the items } \\
\text { revealed silence and } \\
\text { secrecy for } \\
\text { self-seeking actions, } \\
\text { this part was renamed } \\
\text { as "Self-seeking } \\
\text { Silence". }\end{array}$ & $\begin{array}{l}\text { All of these items } \\
\text { are under the } \\
\text { "Self-seeking" } \\
\text { sub-dimension in } \\
\text { the main scale. } \\
\text { Since the } \\
\text { remaining items } \\
\text { contained the } \\
\text { statement of } \\
\text { opposing for } \\
\text { interest this } \\
\text { sub-dimension was } \\
\text { named as } \\
\text { "Self-seeking } \\
\text { Opposition". }\end{array}$ & $\begin{array}{l}\text { All the items } \\
\text { under this factor, } \\
\text { except for item } \\
18 \text {, are included in } \\
\text { the subscale } \\
\text { "Attitude of } \\
\text { Superordinate and } \\
\text { Workmates" and } \\
\text { the } 18 \text { th item } \\
\text { belongs to the } \\
\text { dimension of } \\
\text { "Efficiency" in the } \\
\text { main scale. }\end{array}$ \\
\hline \multirow{2}{*}{$\begin{array}{l}0 \\
\stackrel{0}{0} \\
\mathscr{U} \\
\mathscr{N}\end{array}$} & Max & 20 & 25 & 20 & 20 & 15 \\
\hline & Min & 4 & 5 & 4 & 4 & 3 \\
\hline
\end{tabular}

Data were collected from a group of 282 teachers to determine whether these factors determined by EFA were confirmed. These teachers are from various branches working in basic education and secondary education institutions in the city of Giresun. CFA application was made with this dataset. The diagram obtained as a result of CFA is shown in Figure 1.

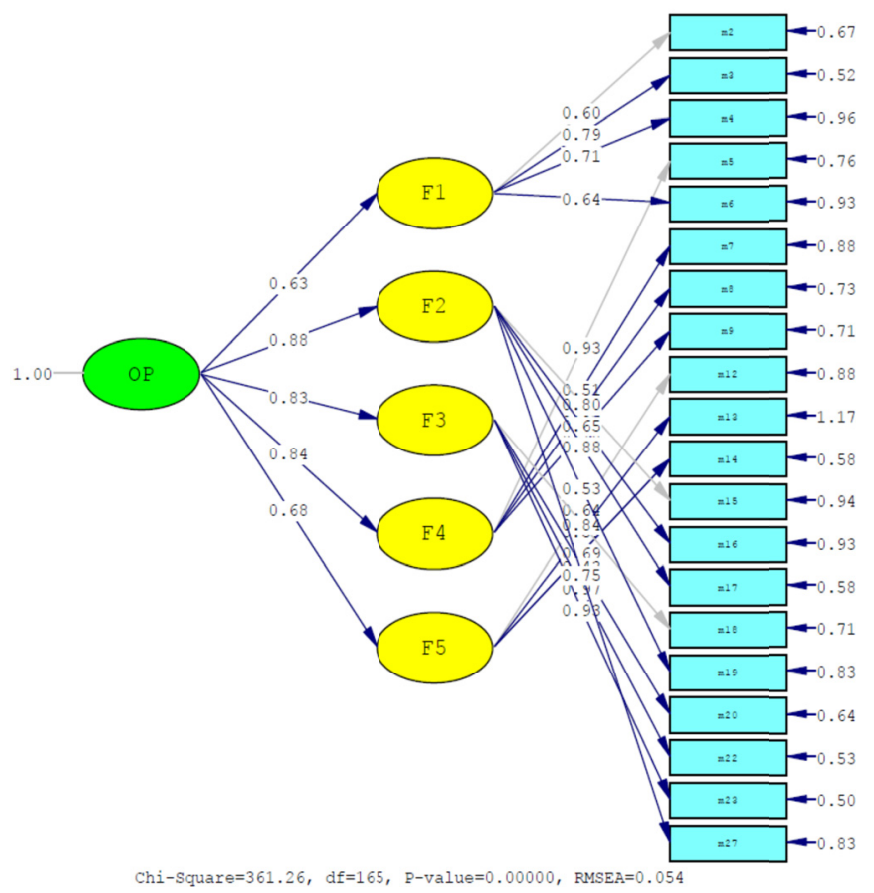

Figure 1. Confirmatory factor analysis model of organizational policy perception (standardized values)

Figure 1 Abbreviations: OP: Organizational Policy Perception, F1: Doing What is Necessary for Promotion-Organizational Attitude, F2: Self-seeking Silent, F3: Attitude of Superordinate and Workmates, F4: Doing What is Necessary for Promotion-Individual Attitude, F5: Self-seeking Opposition

The compliance values obtained as a result of CFA have been summarized in Table 4.

Table 4. Compliance values obtained as a result of confirmatory factor analysis

\begin{tabular}{lllllllllll}
\hline$\chi^{2}$ & sv & $\chi^{2} / \mathrm{sv}$ & RMSEA & AGFI & SRMR & RMR & NNFI & CFI & NFI & IFI \\
\hline 361.26 & 165 & 2.19 & 0.054 & 0.90 & 0.055 & 0.070 & 0.96 & 0.97 & 0.94 & 0.97 \\
\hline
\end{tabular}

The obtained compliance index values are defined as acceptable and perfect values in the literature (Bentler, 1990, Browne 
\& Cudeck, 1993, Çokluk, Şekercioğlu \& Büyüköztürk, 2010, Hu \& Bentler, 1999, Jöreskog \& Sörbom, 1993, Kline, 2005, Marsh, Balla. \& McDonald, 1988; Sumer, 2000, Simsek, 2007, Vieira, 2011). According to these results, it was decided that, with its structure of 20 items and five factors (Doing What is Necessary for Promotion- Organizational Attitude, Doing What is Necessary for Promotion- Individual Attitude, Self-Seeking-Silent, Self-seeking Opposition, Attitude of Superordinate and Workmates) the scale measured teachers' organizational policy perceptions in a valid and reliable way. Reliability of the subscales of the scale was determined as $0.702 ; 0.745 ; 0.760 ; 0.584$ and 0.786 .

\subsubsection{Organizational Ethical Climate Scale}

Views on the perceived organizational ethical climate was gathered with the "Organizational Ethical Climate Scale" (OECS), which was first developed in 1988 by Victor and Cullen as 26 items, and again updated by Cullen, Victor, and Bronson in 1993 with the addition of ten items. The scale which is frequently used to determine ethical decision-making and ethical working climate in organizations were first adapted to Turkish by Sağnak (2005) to be used in educational organizations. The new version of scale was lastly adapted by Özen and Durkan (2016) to be used in educational organizations. According to the results of factor analysis conducted by Özen and Durkan (2016), scale items show a different structure in educational organizations. The scale adapted to educational organizations consists of five factors and 22 items. The scale, which does not contain any reverse scored item, has a five-point Likert-type rating structure. The sub-dimensions of the scale are: "Socially Responsible, Ruled, Self-seeking- Helpful, Principled and Efficient". The highest scores that can be obtained from these dimensions are 35, 20, 20, 20 and 15, respectively; while the lowest scores are 7, 4, 4, 4 and 3 . The reliability of sub-dimensions of the scale was found to be $0.843 ; 0.811 ; 0.614 ; 0.618$ and 0.777 , respectively.

\subsubsection{Corruption Behavior Scale}

The scale was developed by Balc1 et al. (2012) for educational organizations. The scale consists of 24 items. The scale has the five-point Likert-type rating structure. The scale, which does not contain any reversely scored item, gives a total score in one dimension. The highest score that can be obtained from the scale is 120 . The target group to which the scale is applied is working teachers. The reliability of the scale was determined as 0.937 in this research.

\subsection{Universe and Sample}

The universe of the research consists of teachers working in primary education (pre-school, primary school, secondary school) and secondary education institutions in the city of Giresun $(\mathrm{N}=5584)$. Since it was not possible to reach all the teachers, the method of sampling was applied in the research. To calculate the numbers reflected in the sample, Cochran's (1962, Ref. by Balc1, 2004) commonly used formula for determining sample size in a stratified sample was used. According to the formula, 356 people represent the universe of 5584 people at the $5 \%$ tolerance level. In order for scales to be eligible for feedback and to provide data that can be processed, 601 scales were distributed to the field. Within this framework, the number of teachers covered by the research in the city of Giresun, the number included in the sample and the number of teachers evaluated after the collection of data, in other words, teachers who volunteered to fill in the scale prepared for the research, have been presented in Table 5.

Table 5. Universe sample and the number of returning scales

\begin{tabular}{lccc}
\hline School Type & $\begin{array}{c}\text { Total Number of Teachers in the City of } \\
\text { Giresun/Turkey }\end{array}$ & $\begin{array}{c}\text { Number of teachers included in } \\
\text { the sample }\end{array}$ & $\begin{array}{c}\text { Number of scales } \\
\text { evaluated }\end{array}$ \\
\hline $\begin{array}{l}\text { Pre-school } \\
\text { Primary school }\end{array}$ & 349 & 38 & 37 \\
Secondary school & 1.348 & 145 & 107 \\
$\begin{array}{l}\text { Overall secondary } \\
\begin{array}{l}\text { education } \\
\text { Vocational }\end{array}\end{array} \quad$ secondary & 1.695 & 182 & 113 \\
$\begin{array}{l}\text { education } \\
\text { Total }\end{array}$ & 771 & 83 & 55 \\
\hline
\end{tabular}

\subsection{Data Analysis}

Data collected from 406 teachers working in the city of Giresun/Turkey through Corruption Behavior Scale, Organizational Ethical Climate Scale, and Organizational Policy Climate Scale were transferred to IBM-SPSS 22, IBM-AMOS 22 and LISREL 8.8 programs. In line with the purpose of the research, the organizational policy perception data was used as an intermediary variable and the effect of organizational ethical climate on corruption behavior was tested with the path diagram formed.

Path analysis is a special type of structural equation modeling. Structural equation modeling is used to determine the relationship between continuous or discontinuous independent variables and continuous or discontinuous dependent variables. In this model, variables can be observed or latent variables. Structural equation modeling is also called 
"causal modeling analysis" (Tabachnick \& Fidell, 2013, p. 681). "Structural equation modeling is a method for testing causality and structural properties between variables" (Özdamar, 2016, p. 161). Special types of structural equation modeling performed "with only observed variables (without latent variables) are called path analysis" (Özdamar, 2016, p. 218, Tabachnick \& Fidell, 2013, p. 684). There are some benefits of using structural equation models: In the analysis, the measurement error can be estimated and excluded from the model. The analysis also allows for the simultaneous testing of complex relationships and makes it possible to test direct and indirect effects in structural equation models using intermediary variables (Tabachnick \& Fidell, 2013, pp. 684, 686).

\section{Findings}

\subsection{The Relationship Between Organizational Ethical Climate, Organizational Policy Perception and Corruption} Behavior

The ethical climate and organizational policy perception scales consist of five sub-dimensions and the corruption behavior scale consists of one dimension. Relationships regarding the scales and sub-dimensions are as shown in Table 6.

Table 6. Relationships between scales and sub-scales

\begin{tabular}{|c|c|c|c|c|c|c|c|c|c|c|c|c|}
\hline Scales and Sub-scales & & 1 & 2 & 3 & 4 & 5 & 6 & 7 & 8 & 9 & 10 & 11 \\
\hline 1. Socially Responsible & $\begin{array}{l}\mathrm{r} \\
\mathrm{p} \\
\mathrm{N}\end{array}$ & $\begin{array}{l}1 \\
406\end{array}$ & & & & & & & & & & \\
\hline 2. Ruled & $\begin{array}{l}\mathrm{r} \\
\mathrm{p} \\
\mathrm{N}\end{array}$ & $\begin{array}{l}0.583 \\
0.000 \\
406\end{array}$ & 1 & & & & & & & & & \\
\hline 3. Self-seeking Helpful & $\begin{array}{l}\mathrm{r} \\
\mathrm{p} \\
\mathrm{N}\end{array}$ & $\begin{array}{l}0.370 \\
0.000 \\
406\end{array}$ & $\begin{array}{l}0.351 \\
0.000 \\
406\end{array}$ & 1 & & & & & & & & \\
\hline & $\mathrm{r}$ & 0.358 & 0.271 & 0.528 & & & & & & & & \\
\hline 4. Principled & $\begin{array}{l}\mathrm{p} \\
\mathrm{N}\end{array}$ & $\begin{array}{l}0.000 \\
406\end{array}$ & $\begin{array}{l}0.000 \\
406\end{array}$ & $\begin{array}{l}0.000 \\
406\end{array}$ & 1 & & & & & & & \\
\hline 5. Efficient & $\begin{array}{l}\mathrm{r} \\
\mathrm{p} \\
\mathrm{N}\end{array}$ & $\begin{array}{l}0.584 \\
0.000 \\
406\end{array}$ & $\begin{array}{l}0.513 \\
0.000 \\
406\end{array}$ & $\begin{array}{l}0.352 \\
0.000 \\
406\end{array}$ & $\begin{array}{l}0.425 \\
0.000 \\
406\end{array}$ & 1 & & & & & & \\
\hline $\begin{array}{l}\text { 6. DWNP-Organizational } \\
\text { Attitude }\end{array}$ & $\begin{array}{l}\mathrm{r} \\
\mathrm{p} \\
\mathrm{N}\end{array}$ & $\begin{array}{l}-0.398 \\
0.000 \\
406\end{array}$ & $\begin{array}{l}-0.218 \\
0.000 \\
406\end{array}$ & $\begin{array}{l}-0.139 \\
0.005 \\
406\end{array}$ & $\begin{array}{l}-0.195 \\
0.000 \\
406\end{array}$ & $\begin{array}{l}-0.321 \\
0.000 \\
406\end{array}$ & 1 & & & & & \\
\hline 7. DWNP- Individual Attitude & $\begin{array}{l}\mathrm{r} \\
\mathrm{p} \\
\mathrm{N}\end{array}$ & $\begin{array}{l}-0.160 \\
0.001 \\
406\end{array}$ & $\begin{array}{l}-0.071 \\
0.154 \\
406\end{array}$ & $\begin{array}{l}0.088 \\
0.076 \\
406\end{array}$ & $\begin{array}{l}-0.007 \\
0.888 \\
406\end{array}$ & $\begin{array}{l}0.128 \\
0.010 \\
406\end{array}$ & $\begin{array}{l}0.433 \\
0.000 \\
406\end{array}$ & 1 & & & & \\
\hline 8. Self-seeking Silence & $\begin{array}{l}\mathrm{r} \\
\mathrm{p} \\
\mathrm{N}\end{array}$ & $\begin{array}{l}-0.142 \\
0.004 \\
406\end{array}$ & $\begin{array}{l}-0.055 \\
0.271 \\
406\end{array}$ & $\begin{array}{l}0.145 \\
0.003 \\
406\end{array}$ & $\begin{array}{l}0.039 \\
0.434 \\
406\end{array}$ & $\begin{array}{l}-0.064 \\
0.198 \\
406\end{array}$ & $\begin{array}{l}0.371 \\
0.000 \\
406\end{array}$ & $\begin{array}{l}0.573 \\
0.000 \\
406\end{array}$ & 1 & & & \\
\hline 9. Self-seeking Opposition & $\begin{array}{l}\mathrm{r} \\
\mathrm{p} \\
\mathrm{N}\end{array}$ & $\begin{array}{l}-0,156 \\
0.002 \\
406\end{array}$ & $\begin{array}{l}-0.213 \\
0.000 \\
406\end{array}$ & $\begin{array}{l}0.150 \\
0.003 \\
406\end{array}$ & $\begin{array}{l}0.053 \\
0.286 \\
406\end{array}$ & $\begin{array}{l}-0.119 \\
0.016 \\
406\end{array}$ & $\begin{array}{l}0.175 \\
0.000 \\
406\end{array}$ & $\begin{array}{l}0.324 \\
0.000 \\
406\end{array}$ & $\begin{array}{l}0.422 \\
0.000 \\
406\end{array}$ & 1 & & \\
\hline $\begin{array}{l}\text { 10. Attitude of Superordinate } \\
\text { and Workmates }\end{array}$ & $\begin{array}{l}\mathrm{r} \\
\mathrm{p} \\
\mathrm{N}\end{array}$ & $\begin{array}{l}-0.299 \\
0.000 \\
406\end{array}$ & $\begin{array}{l}-0.215 \\
0.000 \\
406\end{array}$ & $\begin{array}{l}0.060 \\
0.225 \\
406\end{array}$ & $\begin{array}{l}0.001 \\
0.990 \\
406\end{array}$ & $\begin{array}{l}-0.222 \\
0.000 \\
406\end{array}$ & $\begin{array}{l}0.418 \\
0.000 \\
406\end{array}$ & $\begin{array}{l}0.504 \\
0.000 \\
406\end{array}$ & $\begin{array}{l}0.553 \\
0.000 \\
406\end{array}$ & $\begin{array}{l}0.468 \\
0.000 \\
406\end{array}$ & 1 & \\
\hline 11. Corruption & $\begin{array}{l}\mathrm{r} \\
\mathrm{p} \\
\mathrm{N}\end{array}$ & $\begin{array}{l}-0.416 \\
0.000 \\
406 \\
\end{array}$ & $\begin{array}{l}-0.390 \\
0.000 \\
406 \\
\end{array}$ & $\begin{array}{l}-0.084 \\
0.090 \\
406 \\
\end{array}$ & $\begin{array}{l}-0.060 \\
0.229 \\
406 \\
\end{array}$ & $\begin{array}{l}-0.283 \\
0.000 \\
406 \\
\end{array}$ & $\begin{array}{l}0.247 \\
0.000 \\
406 \\
\end{array}$ & $\begin{array}{l}0.247 \\
0.000 \\
406\end{array}$ & $\begin{array}{l}0.321 \\
0.000 \\
406 \\
\end{array}$ & $\begin{array}{l}0.287 \\
0.000 \\
406\end{array}$ & $\begin{array}{l}0.453 \\
0.000 \\
406 \\
\end{array}$ & 1 \\
\hline
\end{tabular}

According to Table 6, all sub-dimensions of organizational ethical climate scale (socially responsible, ruled, self-seeking-helpful, principled, efficient) showed significant positive correlations. The "Socially responsible" sub-dimension of organizational ethical climate has a significant negative correlation with all sub-dimensions of organizational policy perception scale and "Corruption Behavior".

The "Ruled" dimension of organizational ethical climate has a negative correlation with the sub-dimensions of "Doing what is necessary for Promotion- Organization attitude, Self-seeking Opposition, Attitude of Superordinate and workmates" of organizational policy perception scale and "Corruption behavior".

The "Self-seeking helpful" sub-dimension of organizational ethical climate showed negative significant correlation with the sub-dimension of "Doing what is necessary for promotion- Organizational Attitude" of organizational policy perception while it showed positive significant correlation with the sub-dimension of "Self-Seeking-Silence, Self-seeking- opposition". 
The "Principled" sub-dimension of organizational ethical climate showed a negative significant correlation with the sub-dimension of "Doing what is necessary for promotion- Organizational attitude" of organizational policy perception. The "principled" sub-dimension did not show a significant relationship with other sub-dimensions of organizational policy perception and corruption behavior scale.

The "Efficient" sub-dimension of organizational ethical climate showed a negative significant correlation with the sub-dimensions of "Doing what is necessary for promotion- Organizational attitude, Doing what is necessary for promotion- Individual attitude, Self-seeking Opposition, Attitude of superordinate and workmates" and with "corruption behavior".

All of the sub-dimensions of organizational policy perception showed positive correlations among themselves and with corruption behavior.

In general terms, as "Socially responsible, Ruled and Efficient" ethical climate perception increases within an organization, organizational policy perception, and corruption behavior decrease; as the perception of "Self-seeking helpful" increases, organizational policy perception, and corruption behavior increase. It can be inferred that there is no relationship between principled perceived ethical climate and organizational policy perception and corruption behavior and as the organizational policy perception increases, corruption behavior increases.

\subsection{The Effect of Organizational Ethical Climate on Unethical Behaviors in the Intermediary Effect of Organizational Policy Perception}

The organizational policy perception was used as an intermediary variable in path analysis, and the indirect effect of organizational ethical climate on unethical behaviors was modeled through this intermediary effect. The resulting model has been shown in Figure 2.

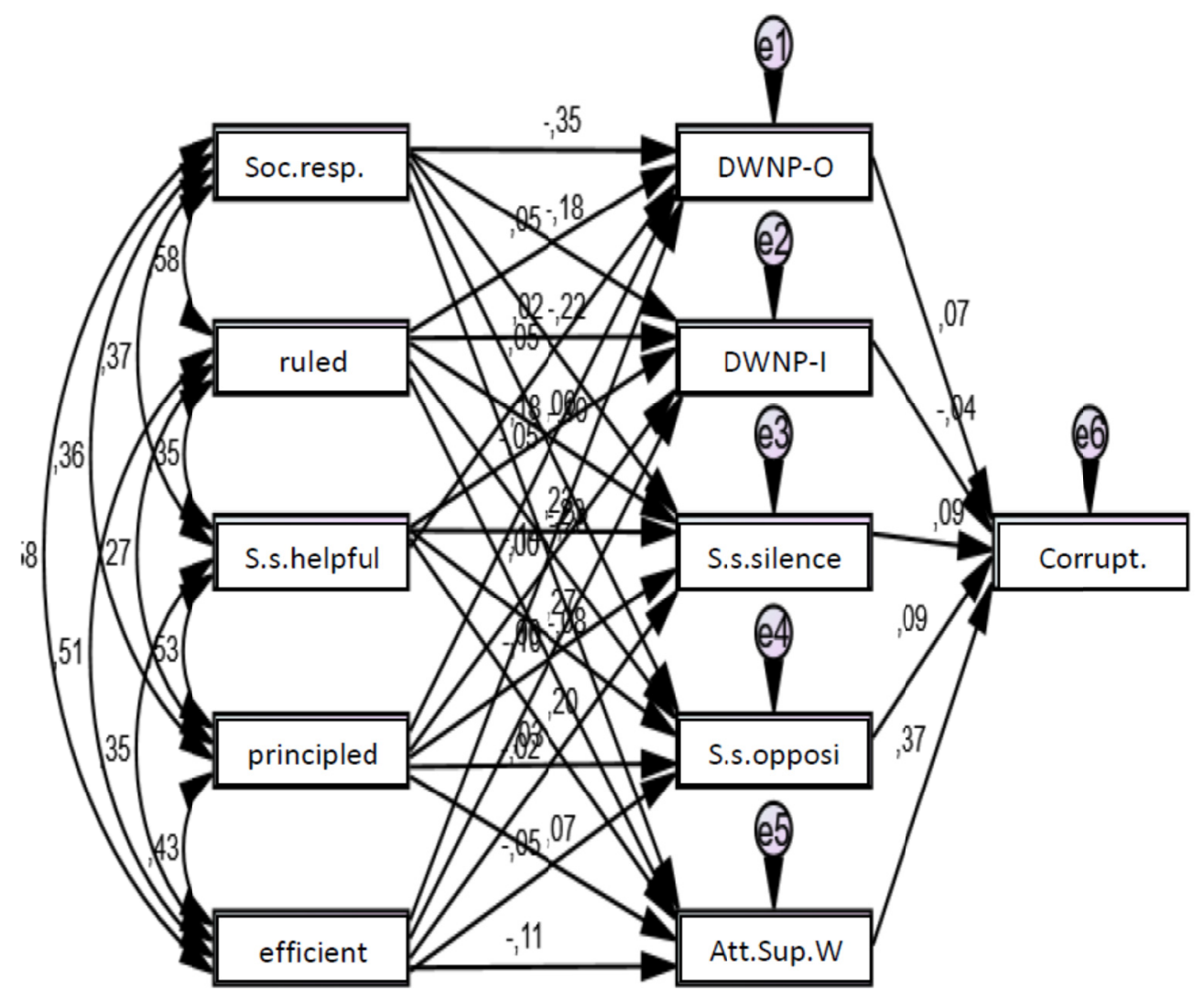

Figure 2. The model of the effect of organizational ethical climate on corruption behavior under the intermediary effect of organizational policy perception (standardized values)

The compliance values obtained for the model shown in Figure 2 have been summarized in Table 6. 
Table 6. The compliance values of the model of the effect of organizational ethical climate on the corruption behavior under the intermediary effect of organizational policy perception

\begin{tabular}{lllllllll}
\hline$\chi^{2}$ & sv & $\chi^{2} / \mathrm{sv}$ & RMSEA & AGFI & RMR & CFI & NFI & IFI \\
\hline 558.939 & 15 & 37.263 & 0.299 & -0.077 & 4.722 & 0.628 & 0.632 & 0.638
\end{tabular}

The obtained compliance index values are acceptable values according to the literature (Bentler, 1990; Browne \& Cudeck, 1993; Çokluk, Şekercioğlu \& Büyüköztürk, 2010; Hu \& Bentler, 1999; Jöreskog \& Sörbom, 1993; Kline, 2005; Sümer, 2000; Şimşek, 2007; Vieira, 2011). According to these results, it can be said that the model of the indirect effects evaluated in the context of intermediary effect cannot be confirmed. Despite the fact that the model is not confirmed, the results of the analysis of possible effects have been examined. The effect of organizational ethical climate on the "Doing what is necessary for promotion- Organizational attitude, Doing what is necessary for promotion- Individual attitude, Self-seeking Silence and Attitude of Superordinate and workmates" is significant $(\mathrm{p}<.05)$. This effect is in the decreasing direction. The decreasing effect of the sub-dimensions of "Rules" of organizational ethical climate on the dimension of "Self-seeking opposition" of organizational policy perception is significant $(p<.05)$. The increasing effect of the sub-dimensions of "Self-seeking helpful" of organizational ethical climate on the "Doing what is necessary for promotion- individual attitude, Self-seeking silence, Self-seeking opposition and Attitude of Superordinate and workmates" of organizational policy perception is significant $(p<.05)$. The decreasing effect of the sub-dimensions of "Efficient" of organizational ethical climate on the "Doing what is necessary for promotion- organizational attitude" of organizational policy perception is significant $(\mathrm{p}<.05)$. The increasing effect of the sub-dimensions of "Attitude of Superordinate and workmates" of organizational policy perception on "Corruption behavior" is significant ( $\mathrm{p}<.05)$.

\subsection{Direct Effect of Organizational Ethical Climate on Corruption Behavior of Teachers}

The direct effect of organizational ethical climate on teachers' corruption behavior has been modeled. The model has been shown in Figure 3.

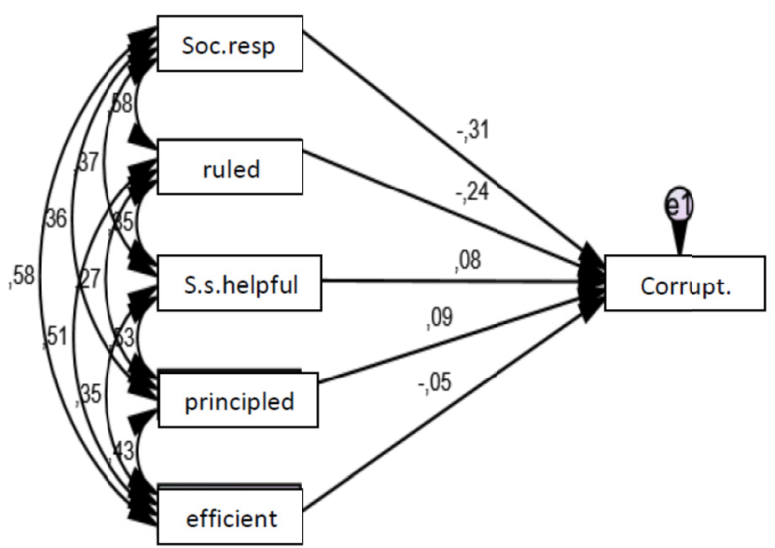

Figure 3. The model of the effect of organizational ethical climate on corruption behavior (standardized values)

The compliance index values of the model are not acceptable values according to the literature (Bentler, 1990; Browne \& Cudeck, 1993; Çokluk, Şekercioğlu \& Büyüköztürk, 2010; Hu \& Bentler, 1999; Jöreskog \& Sörbom, 1993; Kline, 2005; Sümer, 2000; Şimşek, 2007; Vieira, 2011). When the effects were examined, it was determined that the decreasing effect of the "Socially responsible" and "regular" sub-dimensions of the organizational ethical climate on teachers' corruption behavior was significant $(\mathrm{p}<.05)$.

\subsection{Direct Effect of Organizational Policy Perception on Corruption Behavior of Teachers}

The direct effect of organizational policy perception on corruption behavior of teachers has been modeled. The model has been shown in Figure 4. 


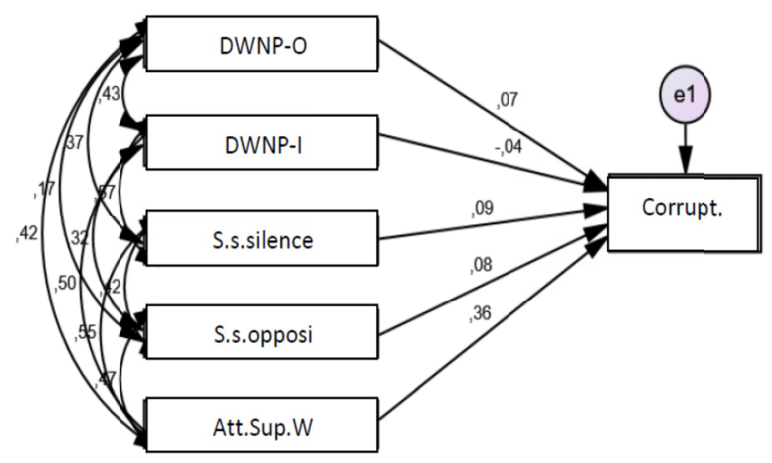

Figure 4. The model of the effect of organizational policy perception on corruption behavior (standardized values)

The compliance index values of the model are not acceptable values according to the literature (Bentler, 1990; Browne \& Cudeck, 1993; Çokluk, Şekercioğlu \& Büyüköztürk, 2010; Hu \& Bentler, 1999; Jöreskog \& Sörbom, 1993; Kline, 2005; Sümer, 2000; Şimşek, 2007; Vieira, 2011). When the effects were examined, it was determined that only "Attitude of superordinate and workmates" had a significant effect on "Corruption behavior" and that it was an increasing effect $(\mathrm{p}<.05)$.

\section{Conclusion and Discussion}

Hull believes that "human behavior is an ongoing interaction between the organism and the environment" (Ref. by Schultz \& Schultz, 202). According to Lewin's (1951) Field Theory, an individual's behavior is a function of the individual's psychological environment. Rotter's simple formula of estimating behaviors is based on the idea of "The more often a behavior is reinforced, the more likely it is that behavior will be reinforced in the future too"(Ref. by Burger, 2004/2006). Thus, it is possible to say that the positive or negative behavior development process of the individual takes place with the influence of both the individual characteristics and the society in which the individual lives and the organization he/she works for; and that the more a behavior is reinforced, the more frequent it is performed by the individual. In this context, this research aimed to reveal the effect of culture-related organizational ethical climate and organizational policy as perceived by employees of the organization on the corruption behavior in educational organizations.

Although the results of this research, which investigated the perceived organizational ethical climate effect on corruption behavior of employees in an educational organization, under the intermediary influence of organizational policy perception did not confirm the model proposed to demonstrate relational effect, positive and negative significant relationships were found between corruption behavior and organizational policy perception and sub-dimensions of organizational ethical climate. For example, when the ethical climate that educational organization employees perceive in their schools is "Social Responsible, Regular and Efficient", the political or corruption behaviors they perceive in their schools relate negatively to these ethical climate types. The ethical climate perceived as "Self-seeking helpful" is positively associated with corruption behavior. All the sub-dimensions of organizational policy perception are positively related to both each other and corruption behavior. This result shows that ethical climate perceived as "self-seeking helpful" ["instrumental" as defined by Cullen, Victor \& Bronson (1993)] in educational organizations is in a positive relationship with organizational policy and corruption behaviors in educational organizations. Similarly, according to the results of the research, the ethical climate perceived as "socially responsible and regular" in educational organizations has a decreasing effect on teachers' corruption behavior; while "attitude of superordinate and workmates" organizational policy perception has an increasing effect on teachers' corruption behavior. Findings of many research carried up to this day show that instrumental ethical climate -apart from the corruption behavior which is the result of this research- has caused many problematic situations in organizations. For example, the results of the research carried out by Deshpande (1996) and Elçi \& Alpkan (2009) show that organizational ethical climate perceived instrumental decreases job satisfaction of the employees of an organization. Results of Wang \& Hsieh's (2013) research show that instrumental ethical climate is positively related to employees' acquiescent silence and in organizations where there is instrumental ethical climate; employees perceive organizational support at a lower level.

The results of this research show that in educational organizations, the ethical climate perceived as "socially responsible and regular" has a decreasing effect on teachers' corruption behavior. The research carried out by Balc1 et al. (2012) on the effect of attitude toward work, organizational culture and work ethics on the corruption behavior of employees in educational organizations (teachers and school administrators) revealed that corruption behavior in educational organizations is significantly related to organizational culture and work ethics in the positive direction while it is less significantly related to attitude toward work in the negative direction. In that case, corruption behavior which is related 
to organizational culture can be reduced by creating a socially responsible and regular ethical climate in educational organizations. In fact, based on the findings of the research, Balc1 et al. (2012) suggested that the development of ethical codes in the organization, in other words, making rules clearer for the reduction of corruption in educational organizations would prevent corruption behavior.

The fact that organizational policy perception that includes the attitude of superordinate and workmates in educational organizations has an increasing effect on the corruption behavior can be explained by "acquiescence", "compliance" or "reflecting" behaviors of employees of the educational organization. In other words, according to the employees of the educational organization, those who engage in corruption in schools are not "them but others" (reflection); or the reason why they engage in corruption in schools may be that "the other employees engage in corruption too" (compliance) or that "the superordinate asks them to do so" (acquiescence). Many studies in social psychology (Asch's studies on group pressure, Sherif's research on norm creation, in other words: Autokinetic effect, Milgram's obedience experiments ...) show that the group in which individuals live or work has effects on their positive and negative behaviors.

\section{Acknowledgements}

A part of this manuscript has been presented as an oral presentation at IX. International Congress of Education Research, held between 11-14 May 2017, at Ordu University, Ordu, Turkey and the abstracts are included in the abstracts of the statements.

\section{References}

Akbaş, T. T. (2010). Örgütsel etik iklimin örgütsel bağlılık üzerindeki etkisi: Mobilya sanayi büyük ölçekli işletmelerinde görgül bir araştırma [The impact of organizational ethical climate on organizational commitment: Empirical research in large-scale enterprises of furniture industry]. KMÜ Sosyal ve Ekonomik Araşttrmalar Dergisi [KMU Social and Economic Researchs Journal], 12(19), 121-37.

Akçakaya, M., \& Hasanoğlu, M. (2009). 21. Yüzyılda kamu personeli: Etik sorunlar ve yeni arayışlar [Public personnel in the 21st century: Ethical problems and new quests]. In Kamu etiği sempozuyum bildirileri 2 [Public ethics symposium notification 2] (pp. 569-586). Publication no: 347. Ankara: TODAIE. Retrieved April 17, 2018 from: http://www.todaie.edu.tr/resimler/ekler/2d735e97a9dd151_ek.pdf

Alpar, C. R. (2011). Uygulamalı çok değişkenli istatistiksel yöntemler [Applied multivariate statistical methods]. Ankara: Detay.

Anderson, J. C., \& Gerbing, D. W. (1984). The effect of sampling error on convergence, improper solutions, and goodness of fit indices for maximum likelihood confirmatory factor analysis. Psychometrika, 49, 155-173. https://doi.org/10.1007/BF02294170

Appelbaum, S. H., Deguire, K. J., \& Lay, M. (2005). The relationship of ethical climate to daviant workplace behaviour. Corporate Governance, 5(4), 43-55. https://doi.org/10.1108/14720700510616587

Aydın, İ. (2014). Eğitim ve ögretimde etik [Ethics in education and training]. Ankara: PegemAkademi.

Balc1, A. (2004). Sosyal bilimlerde araştırma yöntem, teknik ve ilkeler [Research methods, techniques and principles in social sciences]. Ankara: PegemA.

Balc1, A., Özdemir, M., Apaydın, Ç., \& Özen, F. (2012). The relationship of organizational corruption with organizational culture, attitude towards work and work ethics: A search on Turkish high school teachers. Asia Pasific Education Rewiev. 13(1), 137-146. https://doi.org/10.1007/s12564-011-9183-8

Barnett, T., \& Schubert, E. (2002). Perception of the ethical work climate and covenantal relationships. Journal of Ethics, 36(3), 279-290. https://doi.org/10.1023/A:1014042613106

Bentler, P. M. (1990). Comparative fit indexes in structural models. Psychol Bull, 107(2), 238-246. https://doi.org/10.1037/0033-2909.107.2.238

Bıyık, Y., Erden, P., \& Aydoğan, E. (2016). Çalışanların kararlara katılımı ve örgütsel politika algısı ilişkisi [Employee participation in decisions and its relation to organizational policy perception]. Journal of Business Research Turk, 8(1), 100-116. https://doi.org/10.20491/isader.2016.136

Brass, D. J., Butterfield, K. D., \& Skaggs, B. C. (1998). Relationships and unethical behavior: A social network perspective. The Academy of Management Review, 23(1), 14-31. https://doi.org/10.5465/amr.1998.192955

Browne, M. W., \& Cudeck, R. (1989). Single sample cross-validation indexes for covariance structures. Multivariate Behavioral Research, 4(24), 445-455. https://doi.org/10.1207/s15327906mbr2404_4

Burger, J. M. (2006). Kişilik [Personality]. (Interpreter: İ. D. E. Sarığlu). İstanbul: Kaknüs. 
Bursalığlu, Z. (2002). Okul yönetiminde yeni yapı ve davranış [New structure and behavior in school management]. Ankara: Pegem.

Büyüköztürk, Ş. (2013). Sosyal bilimler için veri analizi el kitabı [Manual of data analysis for social sciences.]. Ankara: PegemA.

Büyüköztürk, Ş., Kılıç-Çakmak, E., Akgün, Ö. E., Karadeniz, Ş., \& Demirel, F. (2014). Bilimsel araştırma yöntemleri [Scientific research methods]. Ankara: Pegem.

Çalışlar, A. (1983). Ansiklopedik kültür sözlü̈̆̈̈ [Encyclopedic culture dictionary]. İstanbul: Altın.

Chang, C. H., Rosen, C. C., \& Levy, P. E. (2009). The relationship between perceptions of organizational politics and employee attitudes, strain, and behavior: A meta-analytic examination. Academy of Management Journal, 52(4), 779-801. https://doi.org/10.5465/amj.2009.43670894

Çokluk, Ö., Şekercioğlu, G., \& Büyüköztürk, Ş. (2010). Sosyal bilimler için çok değişkenli istatistik [Multi variabled statistics for social science]. Ankara: PegemAkademi.

Cullen, J. B., Victor, B., \& Bronson, J. W. (1993). The ethical climate questionnaire: An assessment of its development and validity. Psychological Reports, 73, 667-674. https://doi.org/10.2466/pr0.1993.73.2.667

Deshpande, S. P. (1996). The impact of ethical climate types on facets of job satisfaction: An empirical investigation. Journal of Business Ethics, 15, 655-660. https://doi.org/10.1007/BF00411800

Dönertaş, F. C. (2008). Etik iklimin kuruma güven üzerindeki etkisi. (Yayınlanmamış yüksek lisans tezi). Marmara Üniversitesi, İstanbul. [The effect of ethical climate on trust in the institution. (Unpublished master's thesis). Marmara University, Istanbul, Turkey.].

Drucker, P. (2012). Yönetim [Management]. (Interpreter: İ. Gülfidan). İstanbul: Optimist.

Duh, M., Belak, B., \& Milfelner, J. (2010). Core values, culture and ethical climate as constitutional elements of ethical behavior: exploring differences between family and non-family enterprises. Journal of Business Ethics, 97, 473-489. https://doi.org/10.1007/s10551-010-0519-9

Elçi, M. (2005). Örgütlerde etik iklimin personelin vatandaşlık davranışlarına etkileri. (Yayınlanmamış doktora tezi). Gebze Teknik Üniversitesi, Kocaeli [The effects of ethical climate on the citizenship behavior of personnel in organizations. (Unpublished doctoral thesis). Gebze Technical University, Kocaeli, Turkey].

Elçi, M., \& Alpkan, L. (2009). The impact of perceived organizational ethical climate on work satisfaction. Journal of Business Ethics, 84(3), 297-311. https://doi.org/10.1007/s10551-008-9709-0

Erol, E. (2014). Eğitim fakültelerinde örgütsel iklim ile örgütsel politika algısı arasındaki ilişki. (Yayımlanmamış doktora tezi). Pamukkale Üniversitesi Eğitim Bilimleri Enstitüsü, Denizli [The relationship between organizational climate and organizational policy perceptions in education faculties. (Unpublished doctoral thesis). Educational Sciences Institute of Pamukkale University, Denizli, Turkey].

Eser, G. (2007). Etik iklim ve yöneticiye güvenin örgüte bağlılığa etkisi. (Yayınlanmamış yüksek lisans tezi). Marmara Üniversitesi, İstanbul [Ethical climate and managerial confidence in the impact on organizational commitment. (Unpublished master's thesis). Marmara University, Istanbul, Turkey].

Ferris, G. R., Russ, G. S., \& Fandt, P. M. (1989). Politics in organizations. In R.A. Giacalone \& P. Rosenfield (Eds.), Impression management in the organization (pp. 143-170). Hillsdale, NJ: Lawrence Erlbaum.

Fraenkel, J. R., Wallen, N. E., \& Hyun, H. H. (2012). How to design and evaluate research in education. USA: McGraw Hill.

Gelbrich, K., Stedham, Y., \& Gäthke, D. (2016). Cultural discrepancy and national corruption: Investigating the difference between cultural values and practices and its relationship to corrupt behavior. Business Ethics Quarterly, 26(2), 201-225. https://doi.org/10.1017/beq.2016.29

Gorsira, M., Steg, L., Denkers, A., \& Huisman, W. (2018). Corruption in organizations: Ethical climate and individual motives. Administrative Sciences, 8(4), 1-19. https://doi.org/10.3390/admsci8010004

Green, S. B., \& Salkind, N. J. (2008). Using SPSS for windows and Macintosh (Analyzing and understanding data). New Jersey: Pearson.

Gül, H. (2006). Etik dışı davranışlar ve ussallaştırılması: Devlet hastanelerinde bir uygulama [Unethical behaviors and rationalization: An application in state hospitals]. Selçuk Üniversitesi Karaman I.I. B.F Dergisi [Selçuk University Karaman I.I.B.F. Journal], 10(9), 65-79. Retrieved April 06, 2018 from: http://dergipark.gov.tr/kmusekad/issue/10227/125769 
Heynes, F. (2014). Eğitimde etik [The ethical school]. (Interpreter: S. K. Akbaş). İstanbul: Ayrıntı.

Holt, D. H. (1987). Management: Principles and practices. New Jersey: Prentice-Hall.

Hu, L. T., \& Bentler, P. M. (1999). Cut off criteria for fit indexes in covariance structure analysis: conventional criteria versus new alternatives. Structural Equation Modeling: A Multidisciplinary Journal, 6, 1, 1-55. https://doi.org/10.1080/10705519909540118

Jahić, H., \& Činjarević, M. (2017). The effect of social progress and education on corruption: A contingency theory perspective. Economic Review-Journal of Economics and Business, XV(1), 19-31.

Jarrett, M. (April, 2017). The 4 types of organizational politics. Harvard Business Review. Retrieved April 12, 2018 from: https://hbr.org/2017/04/the-4-types-of-organizational-politics

Jöreskog, K. G., \& Sörbom, D. (1993). Lisrel 8: Structural equation modeling with the SIMPLIS command language. Hillsdale: Erlbaum.

Kacmar, K. M., \& Baron, R. A. (1999). Organizational politics: The state of the field, links to related processes, and an agenda for future research. In G. R. Ferris (Ed.), Research in human resources management, Vol. 17, pp. 1-39). US: Elsevier .

Kacmar, K. M., \& Ferris, G. R. (1991). Perception of organizational politics scale (POPS): Development and construct validation. Educational ve Psychological Measurement, 51(1), 193-205. https://doi.org/10.1177/0013164491511019

Kline, R. B. (2005). Principles and practice of structural equation modeling. New York: The Guilford.

Lewin, K. (1951). Field theory and social science: Selected theoretical papers. New York: Harper.

Lewis, P. (1985). Defining business ethics: Like nailing jello to a wall. Journal of Business Ethics, 4, 377-383. https://doi.org/10.1007/BF02388590

Marsh, H. W., Balla, J. R., \& McDonald, R. P. (1988). Goodness-of-fit indices in confirmatory factor analysis: The effect of sample size. Psychological Bulletin, 103(3), 391-410. https://doi.org/10.1037/0033-2909.103.3.391

McShane, S. L., \& Von Glinov, M. A. (2016). Örgütsel davranış [Organizational behavior]. (Interpreter: A. Günsel \& S. Bozkurt). Ankara: Nobel.

Mintzberg, H. (1983). Power in and around organizations. Englewood Cliffs, NJ: Prentice Hall.

Moore, H. L., \& Moore, T. W. (2014). The effect of ethical climate on the organizational commitment of faculty members. Journal of Academic and Business Ethics, 9, 1-15. Retrieved April 09, 2018 from: http://www.aabri.com/manuscripts/142107.pdf

Neale, M. A., \& Northcraft, G. B. (1991). Behavioral negotiation theory: A framework for conceptualizing dyadic bargaining. In L. Cummings \& B. Straw, (Eds.). Research on Organizational Behavior. Greenwich, CT: JAI.

Özdamar, K. (2013). Paket programlar ile istatistiksel veri analizi [Statistical data analysis with packet programs]. Eskişehir: Nisan.

Özdamar, K. (2016). Eğitim, sağlık ve davranış bilimlerinde ölçek ve test geliştirme yapısal eşitlik modellemesi [Modeling of structural equality in scale and test development in education, health and behavioral sciences]. Eskişehir: Nisan.

Özdemir, M. (2008). Kamu yönetiminde etik [Ethic in public administration]. Zonguldak Karaelmas Üniversitesi Sosyal Bilimler Dergisi [Zonguldak Karaelmas University Social Science Journal], 4(7), 179-195.

Özen, F., \& Durkan, E. (2016). Algılanan örgütsel etik iklim ile öğretmenlik meslek etiği arasındaki ilişki [The relationship between perceived organizational ethical climate and teaching profession ethics.]. Kuram ve Uygulamada Eğitim Yönetimi Dergisi [Educational Administration: Theory and Practice], 22(4), 593-627. 10.14527/kuey.2016.023.

Regulation on the Assignment of Administrators of Educational Institutions, (2015, April 22). Official Gazette (No: 30046). Retrieved April 09, 2018 from: http://www.resmigazete.gov.tr/eskiler/2017/04/20170422-6.htm

Robbins, S. P., \& Judge, T. A. (2012). Örgütsel davranış [Organizational behavior]. (Interpreter: İ. Erdem). İstanbul: Nobel.

Rong, Z., \& Cao, G. (2015). A framework for research and practice: Relationship among perception of organizational politics, perceived organization support, organizational commitment and work engagements. Open Journal of Business and Management, 3, 433-440. https://doi.org/10.4236/ojbm.2015.34043

Sağnak, M. (2005). İlköğretimde görevli yönetici ve öğretmenlerin etik iklim türlerine ilişkin algı ve doyum düzeyleri 
[Perception and satisfaction levels of teachers and managers in primary education about ethical climate types]. Eğitim Araştırmaları [Education Research], 5, 203-211.

Schultz, D. P., \& Schultz, S. E. (2002). Modern psikoloji tarihi [A history of modern psychology]. (Interpreter: Y. Aslay). İstanbul: Kaknüs.

Şimşek, Ö. F. (2007). Yapısal eşitlik modellemesine giriş: Temel ilkeler ve LISREL uygulamaları [Introduction to structural equation modeling: Basic principles and LISREL applications]. İstanbul: Ekinoks.

Sökmen, A. (2003). Yönetici etik davranış ve eğitimin sınır birim işgörenleri tarafından değerlendirilmesi: Ankara'daki dört ve beş yıldızlı konaklama işletmelerinde ampirik bir araştırma. (Yayınlanmamış doktora tezi). Gazi Üniversitesi Eğitim Bilimleri Enstitüsü, Ankara. [Evaluation of managers' ethical behavior by boundary spanning role employees': Empirical research in four and five star accommodation enterprises in Ankara. (Unpublished doctoral thesis). Gazi University Educational Sciences Institute, Ankara, Turkey].

Sökmen, A. Ekmekçioğlu, E. B., \& Çelik, K. (2015). Algılanan örgütsel destek, örgütsel özdeşleşme ve yönetici etik davranış ilişkisi: Araştırma görevlilerine yönelik bir araştırma [The relationship between perceived organizational support, organizational identification, and managers' ethical behavior: Perception of research assistants in universities]. Journal of Business Research Turk, 7(1), 125-144. Retrieved April 09, 2018 from: https://doi.org/10.20491/isader.2015115755

Sümer, N. (2000). Yapısal eşitlik modelleri: Temel kavramlar ve örnek uygulamalar [Structural equation models: Basic concepts and sample applications]. Türk Psikoloji Yazıları [Turkish Psychology Articles], 3(6), 49-73.

Tabachnick, B. G., \& Fidell, L. S. (2013). Using multivariate statistics. Boston: Pearson.

Treadway, D. C., Ferris, G. R.., Hochwarter, W. A., Perrewé, P. L., Witt, L. A., \& Goodman, J. M. (2005). The role of age in perceptions of politics job performance relationship: A three-study constructive replication. Journal of Applied Psychology, 90(5), 872-881. https://doi.org/10.1037/0021-9010.90.5.872

Tütüncü, Ö., \& Savran, G. (2007). Etik iklim ve tükenmişlik sendromunun kalite yönetim sistemi üzerine etkileri: Bir laboratuar uygulamas1 [The effects of ethical climate and burnout syndrome on the quality management system: a laboratory practice]. Dokuz Eylül Üniversitesi Sosyal Bilimler Enstitüsü Dergisi [Dokuz Eylül University Institute of Social Sciences Journal]. 9(4), 177-218.

Victor, B., \& Cullen, J. B. (1987). A theory and measure of ethical climate in organizations. In W. C. Frederick (ed.), Research in corporate social performance (pp. 57-71). Greenwich, CT: JAI.

Victor, B., \& Cullen, J. B. (1988). The organizational basis of ethical work climates. Administrative Science Quarterly, 33, 1 Retrieved April 11, 2018 from: https://doi.org/10.2307/2392857

Vieira A. L. (2011). Preparation of the analysis. Interactive LISREL in practice. London: Springer. https://doi.org/10.1007/978-3-642-18044-6

Wang, Y., \& Hsieh, H. (2013). Organizational ethical climate, perceived organizational support, and employee silence: A cross level investigation. Human Relations, 66(6), 783-802. https://doi.org/10.1177/0018726712460706

Wimbush, J. C., \& Shepard, J. M. (1994). Toward an understanding of ethical climate: Its relationship to ethical behavior and supervisory influence. Journal of Business Ethics, 13(8), 637-647. https://doi.org/10.1007/BF00871811

\section{Copyrights}

Copyright for this article is retained by the author(s), with first publication rights granted to the journal.

This is an open-access article distributed under the terms and conditions of the Creative Commons Attribution license which permits unrestricted use, distribution, and reproduction in any medium, provided the original work is properly cited. 